\title{
THE REALIZATION OF LEGISLATIVE MEASURE OF THE RIGHTS OF THE CHILD POST-SECOND AMANDEMENT OF THE CONSTITUTION
}

\author{
M Nur Rasyid \\ Associate Professor of Law, Syiah Kuala University \\ E-mail: nur.rasyid99@gmail.com
}

\begin{abstract}
The government has obligation to protect the rights of the child. In the second amendment of Indonesian Constitution of 1945 in 2000 it was added one chapter, namely Chapter XA on human rights. The rights of the child is incorporated in the Article 28B that stipulated every child entitles to life, growth, develop and to get protection from violence and discrimination.

The problem is how the legislative measure of the rights of the child as the implementation of Article 28B. The data were obtained through library research consist of acts related to protection and judiciary of the rights of the child and the related conventions. The result of the research shows that the government has undertaken legislative measures by making act on child protection, Act Number 23 of 2002 on child protection that has been revised as Act Number 35 of 2014, and the second revision by Act Number 17 of 2016 following the Government Regulation substituted Act Number 1 of 2016. Act Number 3 of 1997 has been revised on Child Judiciary become Act Number 11 of 2012 on Child Criminal Justice System. It needs synchronization of various related regulations and capacity building for the institutions of child protection.
\end{abstract}

Keywords: The rights of the child, child protection, legislative measure, synchronization.

\section{A. INTRODUCTION}

The modern constitution generally consist of the rights of the people, political objective, and government goal (Wheare, 2005: 52), besides the structure of principals organ of a state. The amendment of the constitution that added the rights of the people usually conducted after revolution or reform taken place. The national reform in Indonesia happened in 1998 has been followed by various important changes in the Constitution of Republic of Indonesia. A number of political aspects those underwent fundamental changes in the Constitution of Republic of Indonesia. This constitution amendment has been done four times, 
namely the first amendment in 1999, the second amendment in 2000, the third amendment in 2001, and the fourth amendment in 2002.

In the second amendment of 2000 it was added one chapter, viz. chapter XA on Human Rights consist of 10 articles. Because of that, The United Nation Commission of The Rights of The Child appreciates that Indonesia has incorporated The Rights of The Child as Human Rights in the Constitution in 2000 (Ministry of Foreign Affair, 2008: 100).

The Provision of the Rights of The Child only one verse in the article 28B verse (2) that stipulated that every child entitle to life, grow and developed and entitle to protection from violence and discrimination. In the human rights agenda, child rights have a prominent position centered on the Convention on the Rights of the Child (CRC) (Fottrell, 1999: 168).

The next important measure is how legislative measure of the rights of the child as the realization of the provisions in the article $28 \mathrm{~B}$ verse (2) of the constitution of 1945, since those provisions only basic principles on the protection of the rights of the child. All basic principles need to be reformulated in the statute containing the operational norm, such as Law on the child protection.

The rights of the child is an integral part of the human rights (Unicef, 2003: 4) that has been formulated in the CRC that ratified by the government of Indonesia by Presidential Decision number 36 of 1990. The rights of the child in the constitution and all related statute to the rights of the child must be adjusted to the provision in the constitution. The convention itself emphasizes the need of full realization by legislative measure in accordance with the fulfillment of the rights of the child, beside administrative measure that conducted by the state party to the convention.

The regulation of the rights of the child in the statute is a form of legislative measure that also ordered by the article 2 verse (1) of International Covenant on Economic Social and Cultural Rights (ICESCR) that had been acceded by Indonesia Government through Law Number 11 of 2005.

There is a close relationship between both human rights instrument. Yuri Kolosov (2000: 262) explained that the convention covers various sets of rights: civil and political; social, economic and cultural; and specific rights of children in difficult circumstances.... This explanation is important to remind us that all rights of the child is related to a number of conventions.

The article 4 of the CRC stated that, States Parties shall undertake all appropriate legislative, administrative, and other measures for the implementation of the rights recognized in the present Convention. With regard to economic, social and cultural rights, States Parties shall undertake such measures to the maximum extent of their available resources and, where needed, within the 
framework of international co-operation. For international co-operation, The UN has established a special agency viz. UNICEF, meanwhile for this purpose in UN system there is a Committee of The Rights of The Child within the High Commissioner of the Human Rights.

In the international human rights law there are four forms of state obligation, namely to respect, to protect, to fulfill, and to promote the human rights, including the rights of the child. In the first state of the realization, the obligation of the state party is to undertake the legislative measure to make statute to enable the implementation of all related provision in the convention. In relation to implementation of the rights of the child of the convention and the constitution of 1945 conducted by making and adjusting all statute on the protection and the judiciary of the child.

CRC demand the full realization by the state parties of all recognize rights of the child progressively. To keep in mind that it is not easy to implement the provision in the convention without national legal basis of a state there are a number of gaps between the principals in the CRC and national law of a state.

The Legislation as a return law according to the theory of Trias Politica conducted by legislative institution, especially the parliament. In the Indonesia legal system the legislative power also possessed by executive organ (President and Vice President), to make law together. In the context of implementation of the rights of the child, the obligation of Indonesia as a state party to make law also related to the article 2 verse (2) of ICESCR that stipulated the realization of the recognize rights of the CRC.

Nowadays, the child situation is more and more vulnerable of child abuse result from globalization and more sophisticated of the telecommunication and information media thus can be used for child abuse. These practices can be happening in various forms and in the all transnational organized crime destined to gain financial profit. International Labor Organization (ILO) reported that there are 1,2 million children thus become the victim of human trafficking every year and the United State Embassy in Jakarta also reported that the citizen of Indonesia has become the victim of human trafficking more than 1 million (https ://id.usembassy.gov/id/ laporanitahunan- perdagangan-orang-2017/). The crime using internet also involves the children, which it is necessary legal regulation that created the protection for children (Pulungan dan Makarim, 2004: 197-202).

Along with recognition of importance of child protection this state have the crucial role to protect the rights of the child (Simmons, 2009: 309), there the Government of Indonesia also increase its role significantly in the realization of the protection of the child rights. This action is created by revision of legislation. 
On the basis of above explanation, it is deemed necessary to conduct the research pertaining to the realization of legislative measure on creation and revision of law on the protection of the child and judiciary following the article $28 \mathrm{~B}$ verse (2) of the Indonesia Constitution and article 4 verse (2) of the CRC.

\section{B. PROBLEM STATEMENT}

The research problem is formulated as follow: how did the realization of legislative measure conducted by the Government of Indonesia in the area of the rights of the child post-second amendment of the constitution of 1945.

\section{RESEARCH METHODS}

This research make used the secondary data consist of legislation concerning the protection of the rights of the child and child criminal justice made after the second amendment the constitution of 1945 in 2000, consist of Law on Child Protection and Law on Child Criminal Justice. Based on the data that used and the nature of the juridical-normative research in this research applied statute approach. Data analysis conducted in qualitative technique by legal interpretation and synchronization of the provisions of the related Laws. Data gathering collected by library research to select the important part of Law on the Child Protection and the Law on Child Criminal Justice System.

The objective of this research is to encourage the improvement of the synchronization, the relevance, and affirmative action of the obligation holder of the child protection and related law enforcement institution so that they are able to respond the child situation including transnational action.

\section{DISCUSSION AND RESULT}

The result of the research show that there are two categories of act related to the rights of the child as the realization of the legislative measure and as the implementation of the article 28B verse (2) of the constitution 1945. Firstly, the Law on the Protection of the Child and secondly, the Law on the Child Criminal Justice System. In both acts selected several important articles to be discussed.

The first category of the Law on the Child Protection comprise of Law Number 23 of 2002 on Child Protection, Law Number 35 of 2014 on The Revision of Law Number 23 on 2002 on Child Protection and Law Number 17 of 2016 on The Government Regulation Substitute Law Number 1 of 2016 on The Second Revision of Law Number 23 of 2002 on Child Protection Become Law.

The systematic Law Number 23 of 2002 as is follow, Chapter I General Provision, Chapter II The Principal and The Objective, Chapter III The Child 
Rights and The Responsibilities, Chapter IV Obligation and Responsibilities, Chapter V Child Position, Chapter VI on the Custody Power, Chapter VII Trusteeship, Chapter VIII Parenting and Child Adoption, Chapter IX the Realization of Protection, Chapter X Community Role, Chapter XI The Indonesian Commission on The Protection of the Child, Chapter XII Criminal Provision, Chapter XIII Transitional Provision and Chapter XIV Closing Provision.

In the consideration of Law Number 23 of 2002 on Child Protection, it is stated that Indonesia guarantee the welfare of its citizen, including child protection as a part of human rights. It is clear that from this consideration this legislation is the realization of provision related to the rights of the child as an integral part of human rights. The above consideration is strengthening by following consideration that stated that the rights of the child as human rights recognize as inherence human rights.

The important provision of this research discussed briefly according to legal interpretation technique destined to synchronize the acts related to child protection and judiciary. The definition of child has been adjusted to CRC, namely a child is a person below and including 18 years old of age and including fetus in womb (Article 1 point 1 ). In the Article 1 point 12 also stated the rights of the child as a part of human rights that must be guaranteed, protected, and fulfilled by parent, family, community, government and state. This statement emphasize that the rights of the child is an integral part of international human rights law.

The state and government responsibilities were described in the Article 21 up to Article 24 Law Number 23 of 2002. Article 21 stipulated that the state and the government are obliged and responsible to respect and guarantee the rights of the child without discrimination on the basis of tribe, religion, racial, sex, ethnic, culture, language, legal status, and the physical and mental condition.

The emphasize on the state and government obligation and responsibility are legally binding the state and the government to realize this obligation and responsibility concretely through legislative and administrative measures and action plan that generates positive impact to the protection of child in Indonesia. In the Law Number 35 of 2014 that stated responsibility of state and government stipulated in the Article 21 with the local government responsibility.

In Chapter IX on the Protection there are four most important and heavily implemented articles which are article 66 up to 69. In the Article 66 verse (1) stipulated that the special protection of the child whom exploited economically and sexually constitute obligation and responsibility of government and community. The implementation of this special protection stipulated in verse (2), inter alia, involvement of various government institution, company, labor union, 
non-governmental organization, and community to eliminate the child exploitation economically and sexually. Today's global phenomenon shows that there is an escalation of child exploitation economically in the form of child labor that prohibited by ILO convention. It is more harmful the global phenomenon where the child, especially girl, the victim of sexual exploitation that practice brutally involving a number of parties organizely. In this relation it is need to take into account the implementation the convention against transnational organized crime and its protocol as the important legal instrument to provide protection for child.

In the supervision and control of the implementation of child rights in Indonesia it has been established a Commission for the Protection of Child in Indonesia by the Presidential Decree Number 77 of 2003 to implement the provision of Article 74 Law on Number 23 of 2002. In addition, it has been established previously National Human Rights Commission and National Commission Anti Violence Against Women thus have the mission related to protection of the rights of the child as a part of Human Rights.

Due to complexity of child protection problem, in the realization of human rights, it is necessary to involve a number of parties to solve child problem. Beth A. Simmons explained that "human rights practices are never the results of a single force or factor" ( Simmons, 2009: 5). The KPAI task formulated in the Article 76 to provide existence to the government in realization of the rights of the child.

The other important provision in this act is concerning the child born from international marriage stipulated in the Article 29. The Article 29 verse (1) stipulated that the child who is born from the couple of Indonesia and foreign person is entitled to get the nationality from his/her father nationality or his/her mother nationality. Nevertheless, in the case of divorce happened, the child entitle to choose or based on the decision on the court of law he/she to be under parenting of anyone of the couple concern, and in case of the child is unable to choose, if his/her mother have Indonesia nationality for the best interest of the child or on the request of his/her mother the government is responsible to settle the Indonesia nationality of the child. This provision is more and more important due to escalation of international marriage between Indonesia and foreign citizen result from the fast globalization.

The most important part of this act is the provision in The Chapter III on The Rights and Responsibility of The Child from Article 4 to 19. Article 4 stipulated "every child have the rights to life, growth, and participation properly according to the human dignity, and to have protection from violence and discrimination". This Article emphasize the basic rights of child, comprise of 
rights of life, rights of growth to life, and rights to participation in community in accordance with the human dignity and the rights of the child to the protection from violence and discrimination.

The Article 9 verse (1) stipulated that "every child has the rights to education and guidance in related to his/her personal development accordance with his/her talent and interest. This rights is a part of social rights that stipulated in the International Covenant on Economic, Social and Cultural Rights (ICESCR), in addition to Convention on The Rights of The Child (CRC).

Article 13 verse (1) stipulated that, "every child during his/her parent nurturing, trustee, or any other party who responsible for nurturing, is entitled to protection from any treatment of; a. discrimination; b. exploitation, either economically or sexually; c. neglect; d. cruelty; violence and persecution; e. unfairness; and f. other wrongly treatments". This provision related to a number of conventions, thus are CRC, ILO convention number 182 on worst forms of child labor, and ILO convention number 138 year 1973 on minimum age for employment that ratified by Indonesia in Law number 20 of 1999.

Article 15 stipulated that, "every child is entitled to the protection from; a. political abuse; b. armed conflict involvement; c. social riot involvement; d. activities that contain violence elements; and e. warfare involvement. This provision is important because the child is vulnerable, that is easily influenced by other parties or in his/her live environment. The vulnerability of the child has drawn attention of international community especially by child rights observer. Nowadays, there is a worrying phenomenon where the child easily become the victim of the child abuse that conducted by varies parties with different motif.

Article 16 verse 1 emphasized that, "every child entitled to protection from persecution target, torture, or inhuman punishment". This provision destine to protect the child from varies possibly violence, including the possibility of the occurrence of the child violence in the proceeding of the child criminal justice.

Next, article 3 stipulated that, "arrest, retaining, or imprisonment of the child only conducted if those meet the existing legal provision and only can be done as the last resort". This provision is a vital part of child criminal justice that must be distinguished from the general court of justice so that the child will not suffer from trauma of the others handling, primarily in the proceeding of the child criminal justice. Various states has been applied more human approach in the child court of justice those are the restorative justice approach and diversion policy, so that the child will not alliance from her/his family.

Law number 35 of 2014 on the revision of Law number 23 of 2002 on The Protection of the Child in the article 15 added 1 (one) point, namely point $\mathrm{f}$, so that said, "every child entitled to the protection from; a. political abuse; b. armed 
conflict involvement; c. social riot involvement; $d$. activities that contain violence elements; e. warfare involvement; and f. sexual crime. In the Geneva Convention of 1949 prohibit the involvement of the child in armed conflict and similarly there is the prohibition in the political activities. The worried problem is the abuse of child in economical activities including sexual crime.

Part Two of Act number 35 of 2014 revised the provision of article 21 of Law number 23 of 2002 so that the verse (3) read as follow, "to ensure the fulfillment of the rights of the child as stated in verse (1), the government is obliged and responsible for the formulation and implementation the policies in the child protection realization". This is constituted the emphasized of the government commitments to really come into existence the realization of the protection of the child suitable for everyone expectations. Next, verse (4) stipulated, "to ensure the fulfillment of the rights of the child and to implement the policies as it is mentioned in the article 3, the Local Government are obliged and responsible for implementation and support the national policies in the realization of the protection of the rights of the child in the provinces". One of the policies of the government is the establishment of the Indonesian Commission for the Protection of the Child (KPAI) in all provinces following the Law number 23 of 2002 in article 74 until 76.

The provision in the article 59 of Law number 35 of 2014 revised so read as follows:

1. Government, local government, and others state institutions are obliged and responsible to provide special protection for the child.

2. The special protection for the child as stated in the verse (1) provided to: a. the child in emergency situation; b. the child that conflicts with law; c. the child of the minority groups; d. the child that exploited sexually and/or economically; e. the child who are victimized of narcotics, alcohol, psychotropic, and others addictive substance abusers; f. the child who are victimized by pornography; g. the child who suffered of HIV/AIDS; h. the child victimized of kidnapping, and/or trafficking; i. the child victimized of physical and/or psychological violence; $j$. the child who victimized of sexual crime; $\mathrm{k}$. the child who victimized of terrorism network; 1 . the child with disabilities; $m$. the child who victimized of mistreatment and abandonment; $n$. the child with defiant social behavior; and o. the child who victimized of stigmatization and labeling caused of the conditions of his/her parents. 
The special protections to the child as mentioned above are more concrete and more urgent to be regulated comprehensively. Because, the handling of the child problems are multidimensional those demand the participation of various related parties. In this case it this deemed important to synchronized various similar related regulations or connected each other so that all the regulations on the child protections and the child criminal of justice are in single consolidated regulations. The implementations of this task needs participation of various stakeholders and make use of all potentials experienced resources person available.

Article 1 of Law number 17 of 2016 concerning the Government Regulation Substitute to the Law number 1 of 2016 on the Second Revision of the Law number 23 of 2002 on the Protections of the Child become Law revised article 81 of Law 23 of 2002 as follow:

1. Everyone who violate the provision as stated in the article 76D sentenced at minimum of 5 (five) years imprisonment and at maximum of 15 (fifteen) years and fined maximum at Rp5.000.000.000,00 (five billion rupiah).

2. This provision of the sentence as of article (1) also applied to everyone who intentionally misrepresentation, a series of fraud, or to induce the child to commit congregation with him/her or with others.

3. In case of such wrong doing as of article (1) conducted by parents, trustee, relative, child fosterer, educator, apparatus who deals with child handling, or conducted together by more than one person, the punishment is added $1 / 3$ (one to third) of the sanction as of verse (1).

4. Other than to the perpetrator as of verse 3 , the extra punishment of $1 / 3$ of the sanction also applied to the perpetrator who has been punished cause of offended the article 76D.

5. In case of the wrong doing happen as of article $76 \mathrm{D}$ result in more than 1 victims, cause serious injuries, mental disorders, contagious diseases, dysfunction and lost of reproductive organ, and/or death, the perpetrator condemn to death, live imprisonment, or minimum imprisonment of 10 years and maximum of 20 years.

6. Besides the punishment as of verse 1 , verse 3 , verse 4 and verse 5 , the perpetrator subject to additional punishment that is the announcement of perpetrator identity.

7. To the perpetrator mentioned in the verse 4 and verse 5 might be subject to castrate and implantation of electronic detective device. 
8. The treatments as of point 7 are decided integratedly with the principle sentences by mentioning the spend of time of treatments.

9. Additional sentences and the treatments are excluded from child perpetrator.

Strengthening of the criminal sanction for the perpetrator of the criminal to the child is the primary concern of the government in order to decrease the violation of child rights cases. Also, this article is widened of the legal jurisdiction towards potential parties of the child rights violations, including those who have particular relationship with the child who are victims. Phenomena demonstrated that there are so many child sexual harassments cases that the perpetrators need to be punish heavily.

The second category is Law number 11 of 2012 on the Child Criminal Justice. In the consideration of this act point c, it is emphasized that Indonesia as the party of the Convention on the Rights of the Child that regulated the principle of the legal protection of the child has an obligation to provide special protection to the child who conflicts with law. In the consideration point $\mathrm{d}$, it is emphasized that Law number 3 of 1997 on the Child Criminal Justice is no longer suitable with the society development and the legal needs of the society because of it cannot provide a comprehensive protection to the child who conflicts with law so that should be replaced by another new act.

In the article 1 point 3 defined that the child who are conflicts with law are at minimum 12 years old and maximum 17 years old, as it is also applied for those who became the victims and witness of the crime.

The new concept that incorporated in this Law is restorative justice, namely the settlement process of the case that involves the child perpetrators, victims, family of the perpetrators/victims, and others related parties to seek the fair settlement with emphasizing the restoration to the previous condition and not for the revenge (article 1 point 6). In addition, it is also applied the diversion policy by alter the settlement of the child cases from the criminal justice system to the outside court of law (article 1 point 7).

Justice restorative policy and diversion offer a new opportunity for a better settlement due to it is not merely base on the legal facts, but also base on special consideration that embrace various parties related to the child that conflict with law, thus are community counselor, professional social workers, social welfare facilitators, family/trustee of the child and the child advocates.

The child needs special treatment in the proceeding that different from the adult proceeding, because of the child has not yet mature either physically or spiritual mental. Article 3 stipulated that, every child in the proceeding entitle to: 
a. Treated humanely by considering the needs suitable to his/her age;

b. Separated from adult;

c. To have legal aids and other aids effectively;

d. Conducting recreational activities;

e. Free from torture, other cruel treatment and punishment, inhuman treatment, and degrading his/her dignity;

f. Not sentenced to death or lives sentence;

g. Not captured, detained or imprisoned, except as the last resort and for the minimum time;

h. Received the fairness before the objective child criminal justice, impartial, and in the close proceeding;

i. Not published his/her identity;

j. To have the advocacy of parents/trustee and trusted person of the child;

k. To have social advocacy;

1. To enjoy personal live

m. To have accessibility, primarily for the child with different abilities;

n. To have education;

o. To have health services;

p. To have other rights according to existing regulation.

For the child those conflict with law, the handling of his/her problem not always by legal procedure, because it is possible to choose the consensus way for the best interest of the child. Therefore, the diversion policy might always be applied and no one will lost with the application of this diversion policy. In this relation, article 6 emphasized that the purposes of diversion are:

a. To achieve reconciliation between the child and victims;

b. To settle the child case outside the court of law;

c. To prevent child from freedom deprivation;

d. To encourage society to participate; and

e. To build the sense of responsibility of the child.

Article 21 stated, "in case of the child not yet at age 12 years old conduct or suspected to commit the crime, so the investigator, community counselor, and professional social worker decide;

a. To return to his/her family/trustee; or

b. To join him/her in the educational program, guidance, and counseling in the government institutions or Social Welfare Institutions (LPKS) in the institution that deal with the social welfare, either in the government or local government institution, at least 6 month. 
This legal policy is appropriated because family is the best environment for the child education and guidance that could not be replaced by any others.

The police investigator is not automatically can become an investigator for the child case, since the situation of the child is greatly different from adult. Therefore, every child case investigators have to posses the special capacity that related to the child condition. In this context, article 26 verse 3 stated, "the condition for being child investigator are as follows;

a. Have experience as investigator;

b. Have interest, attention, dedication, and understand the child problems; and

c. Have had the technical training on the child justice system.

The arrestment of the child is different from the adults; therefore article 30 emphasized that, "the arrestment of the child is conducted for the sake of the investigation maximum for 24 hours and it is obliged to place the special child service room". The retainal of the child is limited up to 7 days (article 33) and only can be extended up to 8 days.

The criminal sanction for the child is strictly regulated by stipulation that the child only subject to criminal punishment base on the provision in this Law number 11 of 2012, and the child under 14 years of age only subject to the treatment that regulated in article 69.

There are some kinds of punishment those can be impose on the child who conflict with law as regulated in the article 71, "principle sentence for the child are consisted of warning; conditional punishment; fostering outside the institution; social service or supervision; work training; institutional fostering; and imprisonment. The additional punishment be in the form of; the deprivation of the profit of the child crime; or the fulfillment of customary obligation.

According to these existing regulations, the law enforcement officer in handling the child who conflict with law only allowed to apply the sanction of punishment those enacted in this Law number 11 of 2012, merely for the respect and the protection of the child rights as in an integral part of human rights. No one can forget that all the treatments of the child are in accordance with the four basic principles of the CRC that the core is the principle of the best interest for the child so that there is no other interest.

The implementation of the protection of the rights of the child as part of human rights, it is necessary to connect to the value of the human rights itself which in the child rights context are to pay attention to the child, to understand the 
limits of child responsibility, and to respect the dignity of the child (Fredman, 2009:15) as a human in growing stage.

\section{E. CLOSING}

On the basis of the above mentioned research result and discussion it is clear that the government has already undertaken the realization of legislative measure to implement the provision of article 28(B) verse (2) of Constitution of 1945 and other existing regulations. The realizations of these legislative measures are to adjust the act on child protection and Law on child criminal justice system to the principle of child protection of CRC.

There are a number of provisions in the acts that mentioned above not yet synchronized, therefore it is necessary to synchronize them in order that the implementation of the protection of the child rights and the child trial can be much better than before. Meanwhile, it is necessary to increase the relevancy of the task of the Ministry of Women Empowerment and Child Protection with the existing problem in the protection of the child, because this ministry is the representation of government, in caso the executive power, as well as state representative in dealing with child problems. It is also need to increase the capacity of the law enforcement officers and Indonesian Commission on the Child Protection (KPAI).

\section{BIBLIOGRAPHY:}

\section{Books:}

Fottrell, Deirdre, 1999, "Children's Rights" dalam Hegarty, Angela dan Leonard, Siobhan (Eds). A Human Rights: An Agenda For The 21st Century, Cavendish Publishing: London

Fredman, Sandra, 2009, Human Rights Transformed: Positive Rights and Positive Duties, Oxford University Press: Oxford:

Indonesia. 2008, Kompilasi Rekomendasi Treaty Bodies dan Mekanisme Khusus Perserikatan Bangsa-Bangsa. Direktorat Jenderal Multilateral Departemen Luar Negeri: Jakarta..

Kolosov, Yuri, 2000, “The Rights of the Child” dalam Janusz Symonides (ed.), Human Rights:Concept and Standard, Darmouth Publishing: Aldershot,

Pulungan, M Sofyan dan Edmon Makarim, 2004, "Aspek Hukum Media di Internet", dalam Edmon Makarin (Ed). Kompilasi Hukum Telematika. Jakarta: Rajagrafindo Persada. 
Simmons, Beth A, 2009, Mobilizing for Human Rights: International Law in Domestic Politics. Cambridge University Press: Cambridge.

Unicef, 2003, Pengertian Konvensi Hak Anak. Perwakilan Unicef untuk Indonesia: Jakarta.,.

Wheare, K. C. Konstitusi-Konstitusi Modern (The Modern Constitution), Terj. Muhammad Hardani. Surabaya: Pustaka Eureka, 2005.

\section{Regulations:}

The 1945 Constitution of The Republic of Indonesia.

Law Number 23 of 2002 on The Child Protection. State gazette Number 109 of 2002. TLN Nomor 4235.

Law Number 11 of 2005 on The Ratification of International Covenant on Economic, Social and Cultural Rights . State Gazette Number 118 of 2005

Law Number 11 of 2012 on The Child Judicial System. State Gazette Number 153 of 2012

Law Number 35 of 2014 on The Child Protection. State Gazette Number 297 of 2014

President Decree Number 36 of 1990 on the Ratification of Concention on the Rights of the Child 